\title{
A Critical Discourse Analysis of Concession Speeches Goodluck Jonathan, Kayode Fayemi and Mitt Romney
}

\author{
Stephen M. Anurudu and Tawakalitu Amoo Oduola \\ English Studies Department, University of Port Harcourt
}

\begin{abstract}
Losing an election is not a suitable 'song' that politicians aspire to sing and conceding defeat in public is what no politician ever prays to do. Nonetheless, there must be a winner and there must be a loser especially in a competition as politics. This work investigated the underlying meanings of the concession speeches of President Goodluck Jonathan, Governor Kayode Fayemi and Governor Mitt Romney. The study applied Fairclough and Wodak's Critical Discourse Analysis to analyse the concession speeches of the said politicians. The study is carried out using a qualitative descriptive methodology to analyse the pragmatic, grammatical elements and cohesive devices that are used to decode the ideologies in the speeches. Our findings revealed that politicians concede defeat probably to save face. This means that concession speeches are not actually what they seem to represent rather they are conditional acceptance of the outcome of elections. Our findings also revealed that language use in concession speeches among politicians is similar; this means that the speeches actually follow the same format. This work consequently will be helpful as a resource material to researchers who may want to do further studies on concession speeches.
\end{abstract}

Keywords: concession speech, politics, discourse analysis, cohesive, contrastive

\section{INTRODUCTION}

Language is a common attribute of man. It is used to achieve different purposes but the ultimate reason for language use is effective communication. Also, language is an indispensable tool of persuasion; it determines the level of cooperation between interlocutors and can be used to foster good relations among people across cultures, states and international boundaries. Language in use or the language above the sentence is what discourse entails. Discourse analysis is the analysis of language in use. Political discourse analysis on the other hand is the analysis of political language in use. In politics, a concession speech is the act of a losing candidate publicly yielding to a winning candidate after an election when the outcome of the overall result of the vote has become clear. Concession is optional and a candidate may refuse to concede defeat. This was not the case with President Goodluck Jonathan, Kayode Fayemi and Mitt Romney despite their political differences during the campaigns and the conditions behind losing to General Muhammadu Buhari, Ayodele Fayose and President Barack Obama respectively. They did not see these as obstacles to congratulating the winners of the elections. These speeches were seen as congratulatory messages to a non-linguist but to a discourse analyst, the ideologies behind the speeches revealed that Jonathan, Fayemi and Romney conditionally conceded to the outcome of the election due the love of the Nigerian, Ekiti and American people.

\section{STATEMENT OF THE PROBLEM}

Political concession speeches are new areas of discourse analysis and are uncommon in the political realm, especially in Nigerian politics. Many politicians do not concede defeat after the outcome of elections and those that concede do it mainly for the love of their people. Some politicians see it as a sign of weakness to concede defeat after losing to a candidate. Others tag their speeches congratulatory messages but underlyingly, they are not. Language is a mirror of the mind which reflects what is within the mind even if the interactant tries to conceal it. This study tends to critically unearth the pragmatic and grammatical elements that are present in the concession speeches of Jonathan, Fayemi and Romney to decode their various ideologies about the outcomes of their elections. Ideologies are significant in concession speeches as they unravel the meaning of the unsaid said.

\section{METHODS OF DATA ANALYSIS}

The choice of the texts for this study is informed by a significant nature of the contents of concession speeches. The forms help to decode the social purpose and ideologies of these politicians and these elements are used to convey the actual motives behind their concession speeches to their listeners. The study examines the speeches at the level of pragmatic, grammatical and cohesive devices to arrive at the ideological realms of the 
politicians. The study pays more attention to the cohesiveness of the language of the speeches, the grammatical features and the social and underlying impact of the speeches on the listeners or public.

\section{Concession Speech of President Goodluck Ebele Jonathan}

\section{DATA AND ANALYSIS}

"Fellow Nigerians,

I thank you all for turning out en-masse for the March 28 General Elections. I promised the country free and fair elections. I have kept my word. I have also expanded the space for Nigerians to participate in the democratic process. That is one legacy I will like to see endure. Although some people have expressed mixed feelings about the results announced by the Independent National Electoral Commission (INEC), I urge those who may feel aggrieved to follow due process based on our constitution and our electoral laws, in seeking redress. As I have always affirmed, nobody's ambition is worth the blood of any Nigerian. The unity, stability and progress of our dear country is more important than anything else. I congratulate all Nigerians for successfully going through the process of the March 28th General Elections with the commendable enthusiasm and commitment that was demonstrated nationwide.

I also commend the Security Services for their role in ensuring that the elections were mostly peaceful and violence-free.To my colleagues in the PDP, I thank you for your support. Today, the PDP should be celebrating rather than mourning. We have established a legacy of democratic freedom, transparency, economic growth and free and fair elections.For the past 16 years, we have steered the country away from ethnic and regional politics. We created a Pan-Nigerian political party and brought home to our people the realities of economic development and social transformation. Through patriotism and diligence, we have built the biggest and most patriotic party in Nigerian history. We must stand together as a party and look to the future with renewed optimism. I thank all Nigerians once again for the great opportunity I was given to lead this country and assure you that I will continue to do my best at the helm of national affairs until the end of my tenure.

I have conveyed my personal best wishes to General Muhammadu Buhari. May God Almighty continue to bless the Federal Republic of Nigeria. I thank you all."

\section{'Will of the People' concession speech of Dr. Kayode Fayemi}

In o kun o Ekiti kete"Yesterday, Ekiti State decided. Following the gubernatorial elections held in the land of honour, Ekiti State, Nigeria, the Independent National Electoral Commission (INEC) has officially returned the candidate of the People's Democratic Party (PDP) as the winner of the election. If indeed this is the will of the Ekiti People, I stand in deference to your will. If the result of the elections is an expression of the voice of our people, we must all heed your voice.I have just spoken with my brother, Mr. Peter Ayodele Fayose, congratulating him on his victory. In a few hours from now, I would be meeting the Governor-elect to discuss the future of our dear state and how we would work together to institute a smooth transition programme.It has been a hard fought election. As expected, in the course of the campaigns, there were unsavoury episodes as the candidates toured the nooks and crannies of the state to sell ourselves to the people. Elections tend to be highly divisive affairs that often see brother rising against brother. Despite our diverse party affiliations, and regardless of which way we voted on Saturday, we must remember that we are all sons and daughters of Ekiti State. Ekiti is ours to build together.

On our part, over the course of the campaigns, we presented our scorecards before the people of Ekiti State. We never at any point took your support for granted. We campaigned, we canvassed and we traversed the nooks and crannies of this State. Our performance and achievements in office will remain the backdrop against which the next government and indeed future governments will be assessed. We are proud that with the support of Ekiti people, we have raised the bar of excellence in governance. In all, we gave our best, for conscience and for posterity.Indeed a new sociology of the Ekiti people may have evolved. However, the task of understanding how the outcome of this election has defined us as a people will be that of scholars. For us as an administration and a cadre of political leaders in Ekiti State, we have fought a good fight, we have kept faith.To members of our party, our campaign team and indeed all Ekiti people who defied the siege on our state to cast their votes for our party, I salute your exemplary courage and doggedness in the face of harassment. Thank you for staying the course. The incidences of brazen harassment, intimidation and allied infractions on fundamental human rights, which many of you suffered in the hands of agents of the state, would be documented and communicated to the appropriate authorities, for the records.I thank you all for listening.May God bless the land of honour, Ekiti State, Nigeria. May God bless the Federal Republic of Nigeria." 


\section{Concession Speech of Mitt Romney - Presidential Election 2012}

"Thank you. Thank you. Thank you.

I have just called President Obama to congratulate him on his victory. His supporters and his campaign also deserve congratulations. His supporters and his campaign also deserve congratulations. I wish all of them well, but particularly the president, the first lady and their daughters. This is a time of great challenges for America, and I pray that the president will be successful in guiding our nation. I want to thank Paul Ryan for all that he has done for our campaign and for our country. Besides my wife, Ann, Paul is the best choice I've ever made. And I trust that his intellect and his hard work and his commitment to principle will continue to contribute to the good of our nation. I also want to thank Ann, the love of my life. She would have been a wonderful first lady. She's -- she has been that and more to me and to our family and to the many people that she has touched with her compassion and her care. I thank my sons for their tireless work on behalf of the campaign, and thank their wives and children for taking up the slack as their husbands and dads have spent so many weeks away from home. I want to thank Matt Rhoades and the dedicated campaign team he led. They have made an extraordinary effort not just for me, but also for the country that we love. And to you here tonight, and to the team across the country -- the volunteers, the fundraisers, the donors, the surrogates -- I don't believe that there's ever been an effort in our party that can compare with what you have done over these past years. Thank you so very much. Thanks for all the hours of work, for the calls, for the speeches and appearances, for the resources and for the prayers. You gave deeply from yourselves and performed magnificently. And you inspired us and you humbled us. You've been the very best we could have imagined. The nation, as you know, is at a critical point. At a time like this, we can't risk partisan bickering and political posturing. Our leaders have to reach across the aisle to do the people's work. And we citizens also have to rise to the occasion. We look to our teachers and professors, we count on you not just to teach, but to inspire our children with a passion for learning and discovery.

We look to our pastors and priests and rabbis and counsellors of all kinds to testify of the enduring principles upon which our society is built: honesty, charity, integrity and family. We look to our parents, for in the final analysis everything depends on the success of our homes. We look to job creators of all kinds. We're counting on you to invest, to hire, to step forward. And we look to Democrats and Republicans in government at all levels to put the people before the politics. I believe in America. I believe in the people of America. And I ran for office because I'm concerned about America. This election is over, but our principles endure. I believe that the principles upon which this nation was founded are the only sure guide to a resurgent economy and to renewed greatness. Like so many of you, Paul and I have left everything on the field. We have given our all to this campaign. I so wish -- I so wish that I had been able to fulfil your hopes to lead the country in a different direction, but the nation chose another leader. And so Ann and I join with you to earnestly pray for him and for this great nation. Thank you, and God bless America. You guys are the best. Thank you so much. Thank you. Thanks, guys".

\section{RESULTS AND DISCUSSION: DATA ANALYSIS}

Critical Discourse Analysis of President Goodluck Jonathan's Concession Speech

The concession speech of the 14th Head of State of the Federal Republic of Nigeria, President Goodluck Ebele Jonathan was delivered on 31st March, 2015 after he was defeated by a former military Head of State, President Muhammadu Buhari in the March 28, 2015 presidential election.The speech has a sum of ten paragraphs with a total of fifteen of the first person singular pronoun ' $I$ ', five of the first person plural pronoun 'we', five of 'my' (possessive case of 'I'), four 'you' (the second person singular/plural pronoun), four 'our' (the possessive case of 'we'), and one 'your' (the possessive form of 'you).These pronominal elements have been painstakingly highlighted to reveal how Jonathan uses the elements to reflect his political stance of inclusion and exclusion. He used the first person pronoun ' $I$ ' extensively in his speech to show his responsibilities for and acceptance of the result of the March 28, 2015 presidential election. He used 'I' to show inclusion to take responsibilities for the electoral processes.1. I promised the country free and fair elections. I have kept my word I have also expanded the space for Nigerians to participate in the democratic process. That is one legacy I will like to see endure. Jonathan uses 'I' extensively to personalize the outcome of the election. The ideology behind the use of this personal pronoun 'I' suggests that Jonathan believes that the outcome of the election depend solely on him and if he has not given the concession speech, there would have been chaos in the country. Our analysis reveals that Jonathan projects a form of charismatic leadership, boasting about performance and a positive self-presentation.

2. As I have always affirmed, nobody's ambition is worth the blood of any Nigerian. The unity, stability and progress of our dear country is more important than anything else.

\section{Positive - Self Presentation}

Positive self-presentation is a rhetorical strategy employed by politicians to persuade or manipulate their audience Kamalu and Agangan $(2011, p .41)$. Jonathan presented himself positively in order to orient 
himself to his audience. His main aim is to present his ideology about the outcome of the election in a favourable way.

3. Although, some people have expressed mixed feelings about the results announced by the Independent National Electoral Commission (INEC), I urge those who may feel aggrieved to follow due process based on our constitution and our electoral laws, in seeking redress. In this manner, it is evident that Jonathan is aggrieved about the outcome of the election but he did not state it overtly. Rather, he implored 'those that are not pleased' with the result to seek redress in accordance with the laws of our land. He tried to distance himself from the mourning era of the PDP in order to present a positive face. The ideology behind this is that Jonathan is part of the PDP, therefore 'they' should be celebrating rather than mourning.

5 To my colleagues in the PDP, I thank you for your support. Today, the PDP should be celebrating rather than mourning. Here, Jonathan is excluding himself from mourning and hence on the part of celebrating. This is because mourning by President Jonathan will only bring bloodshed into the country and for peace to reign, Jonathan implores his party and supporters not to mourn.

\section{The Analysis of 'Self'}

The president scores 'self' high regarding the results of the election. He uses 'I' to promise, to assert and to affirm the electoral processes (paragraph 2 -5). It is important to note that ' $\mathrm{I}$ ' is foregrounding in Jonathan's speech. As short as the concession speech is (ten paragraphs) Jonathan uses 'I' fifteen times.

4. I promised the country free and fair election, I have kept my word. I have also expanded the space for Nigerians...I urge those who may feel aggrieved...

In addition, Jonathan uses 'you' only in four places as opposed to the fifteen uses of 'I'. The appreciation 'you' occurs in two places and refers to 'fellow Nigerians'. The 'you' in the fifth paragraph is a solidarity 'you' with his colleagues in PDP. This is further reinforced in 'we' and 'our'. These pronominal are used to legitimize his politics of inclusion.

6. We have established a legacy of democratic freedom.

We created a pan - Nigeria political party and brought to our people the reality of economic development...

We have built the biggest and most patriotic party in Nigerian history.

We must stand together as a party...

Our analysis shows that Jonathan shifts from the first person singular 'I' in which he takes credit for the overall favourable outcome of the electoral processes to the plural 'we' to indicate in-group alliance with his political party and he does it in actual realization that he couldn't have achieved a free and fair election if the party had earlier shown some grievances.Jonathan knew that the party was aggrieved about the election, they did because they were afraid that their party could no longer be the ruling party. This is why Jonathan reminds them that they have steered the country for 16 years. These years, according to Jonathan have been highly laudable.

7. for the past 16 years, we have steered the country away from ethnic and regional politics...

A Statistical Distribution of Pronouns in President Jonathan's Concession Speech
\begin{tabular}{|l|l|l|}
\hline Lexical choice & Frequency of occurrence & Percentage \\
\hline Pronoun (I) & 15 & 44.12 \\
\hline Pronoun (my) & 5 & 14.71 \\
\hline Pronoun (we) & 5 & 14.71 \\
\hline Pronoun (you) & 4 & 11.76 \\
\hline Pronoun (your) & 1 & 2.94 \\
\hline Pronoun (our) & 4 & 11.76 \\
\hline Total & $\mathbf{3 4}$ & $\mathbf{1 0 0}$ \\
\hline
\end{tabular}

The table reveals that the pronoun 'I' has the highest frequency, with $44.12 \%$ of the total pronouns identified in the speech. 'my' takes $14.11 \%$, the first person plural 'we' represents $14.11 \%$ as well and the second person plural pronoun 'you' represents $11.76 \%$. Also the possessive 'our' represents $11.76 \%$ of the pronouns used. The predominant use of the first person singular ' $\mathrm{I}$ ' suggests individuality and personal achievement over the party as regards the March 28, presidential elections. The data suggests that Jonathan praises his own indulgence and the ideology. Behind this is that if he had acted in accordance with the party's aggrieved nature, there would have been catastrophe in the country. 


\section{References and Linguistic devices - Contrastive Pairs}

8. Today, the PDP should be celebrating rather than mourning.

Jonathan opines that PDP should be celebrating its success as it had steered the affairs of the nation for 16 years. They should not mourn their loss to APC because they have brought home the realities of economic development and social transformations of different kinds to the masses.

\section{Cohesive Devices}

Another significant feature of the data is the use of cohesive devices, prominent in this speech is the additive conjunction 'and' that is used extensively in the speech. This conjunction helps Jonathan to achieve cohesion in his speech. Therefore, his speech is well organized.9. based on our constitution and electoral laws..., economic growth and free and fair election...the great opportunity I was given to lead this country and to assure you that I will continue to do my best...

(i) Anaphoric Referencing

10. I thank all Nigerians once again for the great opportunity I was given to lead this country and I assure you that...

11. To my colleagues in the PDP, I thank you for your support.

An anaphoric reference is a backward looking reference. You in text 10 above looks backward to All Nigerians. It refers to all citizens of Nigeria irrespective of their ages, states of origin etc. Jonathan is a Nigerian, so appreciating all Nigerians in this manner denotes a form of in-group membership which denotes that he has the love of the nation at heart.

(iii.) Also, 'that' serves as a reference marker in the speech.

12. I promised a free and fair election... that is one legacy I will like to see endure. I assure you that I will continue to do my best... I also commend the security services for the role in ensuring that the elections were mostly peaceful and violence free.

Three 'thats' are highlighted from the speech, two are functional while only one is foregrounded. That is one legacy I will like to see endure - cataphoric reference (free and fair election).

In conclusion, our study observes that Jonathan did not violate the maxim of relevance and quantity in his speech. He was concise and straight to the point. The speech was short and well -articulated. Contextually, prior to the election, Jonathan was campaigning all over the country which involved long speeches from him but when he was defeated, he gave a very short concession speech. The ideology here is that, just like his party, Jonathan is also 'mourning'.

\section{Critical Discourse Analysis of Governor Kayode Fayemi’s Concession Speech}

Kayode Fayemi's 'Will of the People' concession speech reveals how language is tactfully used to express Fayemi's dismay about the outcome of the election although he tagged it 'Will of the People' concession speech. Such a study as this informs that in every structure, there is an underlying meaning and this is what Fayemi's speech rightly portrays.

\section{The Power of Discourse Opening}

Discourse opening is that preliminary exchange no matter how brief, designed to start off a conversation. Discourse opening can come in the form of summoning or greeting, Osisanwo (2003, p.11). Greeting serves as phatic communion that introduces the main discussion. It is also a talk initiation tool that creates room for the audience to be eager to hear the interlocutor. Fayemi started his speech by greeting his listeners in the standard dialect of Ekiti.

\section{1. 'In o kun o Ekiti kete'- Greetings to all Citizens of Ekiti}

The greeting means 'greetings to all citizens of Ekiti'. This greeting is not gender or age based but addressed to all the citizens of Ekiti State irrespective of which part of Ekiti they come from. Fayemi has a doctorate degree and using the standard dialect of Ekiti implies that he is well acquainted with the language and culture of his people. He used it to serve as a tool of in-group membership with the people of Ekiti State which in turn creates conducive environment for his conversation. The discourse opening in this regard has an attention arresting potential

\section{Meaning and Cohesion in Discourse}

Cohesion is a meaning relationship that an element has with another element in a text. If the interpretation of any discourse is dependent on making references to another, there is cohesion Emezue (1998). Grammatical cohesion in a text is made possible through reference, substitution, ellipsis and conjunction. Findings reveal that political concession speeches often involve an exophoric reference which takes its meaning outside the linguistic repertoire of the speech. 
a)

Reference

Reference is the relation between language and extra-linguistic reality. It can also be seen as a relationship between a particular expression and what it denotes in the outside world. Reference has to do with retrieving information for referential meaning. There are two types of co-referential relations. These are endophoric and exophoric references. An endophoric reference takes its meaning within the text while an exophoric reference takes its meaning outside the text.

\section{(i) Exophoric Reference}

The exophoric reference has to do with a situation where the meaning of an expression is extra-textual. In other words, the referential meaning cannot be located in the given text. The reader or analysts may have to think outside the particular text for full realisation of meaning. An example of this reference is evident in the second paragraph of Fayemi's Speech.

2. If indeed this is the will of the Ekiti people

'This' in the data above is an exophoric reference. Its meaning lies outside the text and it refers to the outcome of the gubernatorial election that took place on Saturday, 21st June, 2014 in Ekiti State.

\section{(ii) Endophoric Reference}

This takes its meaning within the text and the listeners do not have to look outside the text to deduce the meaning of such referential element.

3. It has been a hard fought election. As expected in the course of the campaigns, there were unsavoury episodes as the candidates toured the nooks and crannies of the state to sell ourselves to the people. Elections tend to be highly divisive affairs that often see brother rising against brother.

The meaning of the expression above is intra-textual. Fayemi expressed that election tend to be a hard fought one as it sees brother rising against brother. This is true of the electoral system of our country as election is actually a game of survival of the fittest.

\section{(iii) Cataphoric and Anaphoric References}

A cataphoric reference is a kind of reference which is forward looking. The analyst has to look forward to get the desired meaning personal pronouns like 'he', 'she', 'it', 'the' and other pro-forms, which anticipate the noun phrases with which they co-occur are used.

4. I have just spoken with my brother, Mr. Peter Ayodele Fayose, congratulating him on his victory.

'My brother' in this regard is a cataphoric reference, it looks forward to Mr. Peter Ayodele Fayose while 'him' and 'his' look backward to Mr. Peter Ayodele Fayose.

The ideology behind referring to Mr. Peter Ayodele Fayose as 'my brother' by Fayemi implies that they belong to the same fraternity and despite their political differences they are sons of Ekiti State and politics should not separate them.

-Anaphoric reference on its part is a form of backward looking reference. The analyst has to look backward to get the desired meaning. Personal pronouns - 'he', 'she', 'it', 'they' function typically with anaphoric reference. Definite article 'the' and demonstrative like 'that' can also be used to make anaphoric reference.

5. Yesterday, Ekiti State decided following the gubernatorial elections held in the land of honour.

The land of honour in this regard is an anaphoric reference and it looks back to 'Ekiti State'. Fayemi did not want to repeat Ekiti State and that was why he substituted it with the land of honour. The ideology behind substituting Ekiti State, for the land of honour signifies that something dishonourable has happened in 'the land of honour', Ekiti State.

\section{(b) Conjunction}

This is a grammatical device used to achieve cohesion, it involves the use of conjuncts like 'and', 'although', 'but' etc. Fayemi uses conjunct 'and' extensively in his speech to achieve cohesion.

6. (i) I would be meeting the Governor-elect to discuss the future of our dear state and how we would work together to institute a smooth transition programme.

(ii) Despite our diverse party affiliation, and regardless of which way we voted on Saturday, we must remember that we are all sons and daughters of Ekiti State.

(iii) We campaigned, we canvassed and we traversed the nooks and crannies of Ekiti State.

Fayemi used 'and' as a tool for unity. This means that they should all be united and despite which way they all voted on Saturday, Ekiti is theirs to build and this takes a collective effort. This is because having lost the 
election Fayemi and his party members should not disassociate themselves from the progress of Ekiti State as they all originate from this State.

\section{c) Substitution}

This entails replacing an element which could be a word, group or clause with a word in the next clause.

7. I have just spoken with my brother, Mr. Peter Ayodele Fayose ..., the governor elect. Yesterday, Ekiti State decided following the gubernatorial elections held in the land of honour.

\section{Parallelism}

The use of components that are grammatically the same denotes parallelism. These components are similar in their construction, sound, meaning or meter. It adds balance and rhythm to sentences giving ideas of a smoother flow and thus can be persuasive because of the repetition it employs. Fayemi employs parallel structures to convince his listeners as well as his party members on the depth of campaign carried out by them. Fayemi expresses that;

\section{We campaigned, we canvassed and we traversed the nooks and crannies of this state.}

Our performance and achievements in office will remain the backdrop against which the next government and indeed future governments will be assessed. We are proud that with the support of Ekiti people, we have raised the bar of excellence in governance. In all we gave our best, for conscience and posterity.

These parallel structures imply that their campaigns actually took them to different parts of Ekiti State both immediate and remote places. They canvassed by promising the people what they would do for them if elected. This signifies that election is actually a game of numbers.

\section{Intertextuality and Fayemi's Speech}

Intertextuality is the shaping of a text's meaning by another text. It implies the way in which texts gain meaning through their referencing or evocation of other texts. When writers borrow from previous texts, their work acquires layers of meaning.Also, when a text is read in the light of another text, all assumptions and effects of the other text give a new meaning and influence the way of interpreting the original text. Fayemi's speech is an instance of intertextuality with the Bible. He consoled himself with a quote from II Timothy 4:6-8 in the last line of the sixth paragraph of his speech.

9. Indeed, a new sociology of the Ekiti people may have evolved. However, the task of understanding how the outcome of this election has defined us as a people will be that of scholars. For us at the administration and a cadre of political leaders in Ekiti state, we have fought a good fight, we have kept faith.

\section{Timothy 4: $6-8$}

For I am already being poured out like a drink offering, and the time for my departure is near. I have fought the fight, I have finished the race, I have kept faith. Now there is in store for me the crown of righteousness, which the Lord the righteous judge, will award me on that day, and not only to me, but also to all who have longed for his appearing.Fayemi did not complete the Bible verse above, he stopped at 'we have fought a good fight, we have kept faith'. He omitted the part that denotes the completion of his course. The ideology behind not completing the verse suggests that Fayemi did not actually complete his course. If he had been elected to run for the second term, he would have finished all the projects he started at the beginning of his tenure. This would have denoted the completion of his course. The quote suggests that politics in Nigeria is really a game of fight, it is all about the survival of the fittest.In summary Kamalu and Otu, (2011) perceive an intertextual relation as

....an enquiry for intertextual relationships between discourses does not amount to investigating their sources in order for determine their originality or discredit their users. Rather, it enables the reader to connect the ideological and semantic components of a text with that of an initiant text and thus interpret the former within a particular histo-cultural semiotic (573)

\section{The Role of 'if'}

10. If indeed this is the will of the Ekiti people I stand in deference to your will. If the result of the deference is an expression of the voice of our people, we must all heed your voice.

Fayemi used 'if' in two places in the speech. He used it to express the doubtful state of his mind as regards the lack of credibility of the election. He expressed some doubts about the outcome of the election and he stated the condition on which he could accept the outcome of the polls. That is, if it was actually the will of the people to replace him with Mr. Peter Ayodele Fayose. 


\section{Analysis of Pronominal Elements}

Pronoun reference is always important in putting over a piece of political persuasion. Pronouns are typical deictics for political contexts and their categories throughout the same political speech, such pronominal self-references may of course vary, depending on which reference group is most relevant for each argument. Principles of exclusion and inclusion are at play and they reflect the partisan strategies of power in the political process. Politicians use in their speeches pronouns that are worth looking at because they make significant contributions in their speeches and so are the pronouns in the concession speeches of the politicians under study.

\begin{tabular}{|c|c|c|c|}
\hline Pronominal item & Noun antecedent & Referent & Meaning \\
\hline $\begin{array}{l}\text { I stand in deference } \\
\text { to your will. }\end{array}$ & $\begin{array}{l}\text { The people of Ekiti } \\
\text { State. }\end{array}$ & $\begin{array}{l}\text { The good people } \\
\text { of Ekiti state }\end{array}$ & $\begin{array}{l}\text { Fayemi expresses } \\
\text { respect for the will } \\
\text { of the people of } \\
\text { Ekiti State. }\end{array}$ \\
\hline $\begin{array}{l}\text { We must all heed } \\
\text { your voice }\end{array}$ & \begin{tabular}{lr} 
Fayemi, & Fayose \\
and all other \\
political aspirants \\
including their \\
party members and \\
\multicolumn{2}{l}{ supporters. }
\end{tabular} & $\begin{array}{l}\text { The people of Ekiti } \\
\text { State. }\end{array}$ & $\begin{array}{l}\text { The gubernatorial } \\
\text { candidates whether } \\
\text { pleased or } \\
\text { displeased with the } \\
\text { outcome of the } \\
\text { election should } \\
\text { accept it as the } \\
\text { unanimous voice } \\
\text { and will of the } \\
\text { people which must } \\
\text { be respected. }\end{array}$ \\
\hline $\begin{array}{l}\text { Despite our diverse } \\
\text { party affiliations, } \\
\text { and regardless of } \\
\text { which way we } \\
\text { voted on Saturday, } \\
\text { we must all } \\
\text { remember that we } \\
\text { are all sons and } \\
\text { daughters of Ekiti } \\
\text { State. }\end{array}$ & $\begin{array}{l}\text { The gubernatorial } \\
\text { candidates and all } \\
\text { other political } \\
\text { aspirants }\end{array}$ & $\begin{array}{l}\text { The people of Ekiti } \\
\text { State. }\end{array}$ & $\begin{array}{l}\text { The candidates } \\
\text { should not see the } \\
\text { differences in their } \\
\text { political ideologies } \\
\text { as obstacles against } \\
\text { building Ekiti. The } \\
\text { citizenry on their } \\
\text { parts should not be } \\
\text { constrained by } \\
\text { which way they } \\
\text { voted during the } \\
\text { elections. Building } \\
\text { Ekiti State is a joint } \\
\text { effort by all. }\end{array}$ \\
\hline $\begin{array}{l}\text { I have just spoken } \\
\text { with my brother, } \\
\text { congratulating him } \\
\text { on his victory. }\end{array}$ & Kayode Fayemi & $\begin{array}{l}\text { Mr. Peter Ayodele } \\
\text { Fayose. }\end{array}$ & $\begin{array}{l}\text { He has just spoken } \\
\text { with his political } \\
\text { rival and an } \\
\text { indigene of Ekiti } \\
\text { State } \\
\text { congratulate him } \\
\text { on his victory and } \\
\text { not 'our' victories. }\end{array}$ \\
\hline
\end{tabular}

Personal pronouns used in the text unravel Fayemi's disposition towards the election, hence his ideology. Our analysis reveals that Fayemi used the first person 'I/We' when he wanted to highlight some personal responsibilities for some of the actions of his government as well as his party as regards the gubernatorial election. 'We' is also used for inclusion with the people of Ekiti in order to build the State collectively.

\section{Discourse Closing}

11I thank you all for listening.May God bless the land of honour, Ekiti State, Nigeria.

May God bless the Federal Republic of Nigeria.Discourse closing is the final exchange between interlocutors. It is expected to terminate the discussion. Fayemi ended his speech by thanking the people of Ekiti for listening and prayed for 'the land of honour', Ekiti state. He referred to Nigeria as 'the Federal Republic of Nigeria' and Ekiti State as 'the land of honour'. The ideology behind this is that he was not pleased with the result of the election held in 'the land of honour'. To Fayemi, something dishonourable has happened in 'the land of honour', Ekiti State. 


\section{A Critical Discourse Analysis of Mitt Romney's Concession Speech.}

Mitt Romney delivered his concession speech on Wednesday, 7th November, 2012. It is a 24paragraph speech addressed to the people of America. In the speech, there are some rhetorical devices that portray the political ideology, commitment and personality of Mitt Romney. Like other concession speeches, Romney, opened his discourse by appreciating his audience thereby creating/seeking affinity with them. It is a form of phatic communion that creates conducive atmosphere for his conversation.

This sub-section shall dwell on the analysis of the linguistic elements of the speech and the ideologies encoded in these forms.

\section{The Rhetoric of Appreciation}

Politicians often start their concession speeches by expressing appreciations regarding the outcome of the election that has just defeated them. They congratulate the newly elected politicians, his supporters and their own supporters as well. This is to bring a positive relationship between the politicians and to maintain the spirit of sportsmanship among them.

1. I have just called President Obama to congratulate him on his victory. His supporters and his campaign also deserve congratulation. I wish all of them well, but particularly the president, the first lady and their daughters.

Politicians call their counterpart to congratulate them so that the people will not perceive their grievances about the election initially. The ideology behind these congratulations is to keep a positive face with the newly elected politicians, his supporters and the society in general. The congratulations in this regard denote seeking affinity with the new leader.

\section{Analysis of pronominal devices}

Romney uses 'I' and 'you' - first and second person pronouns extensively in his speech. There are a total of 20 'I's and 19 'yous'. He used the 'I's mostly to appreciate the people that supported his campaign especially Ann, 'the love of his life'. Romney uses 'you' in four different ways. The first category of 'you' refers to the audience present when he was delivering the speech. The second category of 'you' refers to his campaign team which comprises the volunteers, the fundraisers, the donours and the surrogates.

Also, he uses 'you' to refer collectively to the Americans and the last 'you' refers to the job creators/educators. Romney's use of 'you' in his speech has a foregrounding effect as it occurs in 19 times. The appreciation 'you' occurs in 8 times and there are no direct referents but used generally to show appreciation. The in-group membership 'you' occurs four times to show that he is part of the campaign team and his party as a whole.

There are two 'yous' that refer to educators-teachers and professors and job creators. He challenged them to assist in teaching their children based on the principles of the country-honesty, charity, integrity and family. $\mathrm{He}$ implored job creators to invest in and move the country forward. The last group of 'you' used by Romney is the solidarity 'you' which he used to refer to all Americans, these are four in numbers and he used it to challenge the Americans to aspire for the greatness of their country.In view of the 'you' above, Romney uses us, 'our' and 'we' to denote inclusion with the party (campaign team), the audience and the country. The rhetoric of this inclusion is an indication that Romney and every citizen should endeavour to collectively uplift the country.

2 We citizens also have to rise to the occasion.We look to our teachers and professors; we count on you not just to teach, but to inspire our children...We look to our pastors, priest, and rabbis and counselors of all kinds to testify of the enduring principles upon which our society is built...We look to our parents... everything depends on the success of our homes. We look to job creators of all kinds. We're counting on you. We look to democrats and republicans...These 'wes' and ours' show Romney's readiness to work for the success of the nation despite his defeat. He used the 'I' for clarity of his expression and to enhance his personality. The 'I' serves a subjective role in the speech thereby denoting the agent of the discourse. He used the first person plural (we) and its possessive (our) side by side to relate himself with his audience, educators, religious leaders, parents, job creators and his political alliances; democrats and republicans. This he does in order to seek affinity with these group people and it serves as an iota of inclusion. The table below shows the distribution of pronouns in the speech and their meaning/referents.

Table

\begin{tabular}{|l|l|l|l|}
\hline Pronominal item & $\begin{array}{l}\text { Noun } \\
\text { Antecedent }\end{array}$ & Referent & Meaning \\
\hline $\begin{array}{l}\text { And to you here } \\
\text { tonight and to the } \\
\text { team across the } \\
\text { country... I don't }\end{array}$ & None & The audience & $\begin{array}{l}\text { He is appreciating the } \\
\text { support of the } \\
\text { audience and his }\end{array}$ \\
\hline
\end{tabular}




\begin{tabular}{|c|c|c|c|}
\hline $\begin{array}{l}\text { believe } \\
\text { there's ever been } \\
\text { an effort in our } \\
\text { party that can } \\
\text { compare with } \\
\text { what... }\end{array}$ & & & $\begin{array}{l}\text { entire campaign } \\
\text { team. }\end{array}$ \\
\hline $\begin{array}{l}\text {...you have done } \\
\text { over these past } \\
\text { years }\end{array}$ & None & $\begin{array}{l}\text { The team across the } \\
\text { country. The } \\
\text { fundraisers, the } \\
\text { donors, the } \\
\text { volunteers and the } \\
\text { surrogates }\end{array}$ & $\begin{array}{l}\text { He } \\
\text { acknowledges } \\
\text { that without } \\
\text { these people, the } \\
\text { campaign would } \\
\text { not have been a } \\
\text { success although } \\
\text { not fruitful. }\end{array}$ \\
\hline $\begin{array}{l}\text { We are counting } \\
\text { on you to invest, } \\
\text { to hire, to step } \\
\text { forward }\end{array}$ & Job creators & $\begin{array}{l}\text { The job creators } \\
\text { across the country } \\
\text { who can assist to } \\
\text { reduce } \\
\text { unemployment }\end{array}$ & $\begin{array}{l}\text { Romney calls } \\
\text { upon the job } \\
\text { creators to help } \\
\text { in eradicating } \\
\text { youthful } \\
\text { unemployment } \\
\text { and boost the } \\
\text { nation's } \\
\text { economy. }\end{array}$ \\
\hline $\begin{array}{l}\text { I so which that I } \\
\text { had been able to } \\
\text { fulfil your hopes } \\
\text { to lead the country } \\
\text { in a different } \\
\text { direction, but the } \\
\text { nation chose } \\
\text { another leader. } \\
\text { And so Ann and I } \\
\text { join with you to } \\
\text { earnestly pray for } \\
\text { him and this great } \\
\text { nation. }\end{array}$ & None & $\begin{array}{l}\text { The citizens of } \\
\text { America among } \\
\text { whom some are } \\
\text { seated as audience }\end{array}$ & $\begin{array}{l}\text { Romney is } \\
\text { pledging his } \\
\text { allegiance to the } \\
\text { new government } \\
\text { and promising } \\
\text { the nation that he } \\
\text { is going to } \\
\text { cooperate with } \\
\text { them to lift the } \\
\text { nation forward } \\
\text { and with prayers. } \\
\text { Nonetheless, he } \\
\text { is not happy that } \\
\text { the Americans } \\
\text { chose another } \\
\text { leader despite his } \\
\text { preparedness to } \\
\text { serve the nation. }\end{array}$ \\
\hline
\end{tabular}

\section{Other References and rhetorical elements}

Observable in the speech are the following cohesive devices.

\section{(a) Conjunction}

The two kinds of conjunctions that occur in the speech are 'and' and 'but'. These are otherwise known as additive and adversative conjunctions respectively 'and' they are cohesive devices that help a speaker to organise his thought perfectly. Romney uses 'and' to achieve cohesion in his speech.

3. This is a time of great challenges for America and I pray that the president will be successful in guiding our nation.

4. Thanks for all the hours of work, for the calls, for the speeches and appearances, for the resources and for the prayers. You gave deeply from yourselves and performed magnificently. And you inspire us and you humbled us.

The additive 'and' in the excerpts above show that the conjunction helps Romney to have an organized thought and it signifies that Romney appreciates the support he received from the people and particularly the solidarity he enjoyed from his team. The adversative 'but' is used to bridge the gap between the time of the completion of the election and the enduring principles of the nation. 
5. The election is over but our principles endure

The adversative 'but' is also used as a coordinating conjunction in the following excerpts from the speech.

6 ....we count on you not just to teach but to inspire our children.

7. They have made an extraordinary effort not just for me but also for the country that we love

8. I wish all of them well, but particularly the president, the first lady and their daughter.

In addition to coordinating his speech, Romney also used 'but' to show discontentment about the outcome of the election. It reveals his actual emotions and state of mind despite that he concealed it initially by appreciating everybody, but the underlying ideology of his concession speech later re-surfaced. He expressed his discontentment in the excerpt below.

9. I so wish that I had been able to fulfil your hopes to lead the country in a different direction

but the nation chose another leader. And so Ann and I join with you to earnestly pray for

him and for this great nation.

b. Endophoric reference - Cataphoric and Anaphoric

\section{(i) Anaphoric}

I have just called president Obama to congratulate him on his victory. His supporters and his campaign also deserve congratulations.

I want to thank Paul Ryan for all he has done for our campaign. And I trust that his intellect and his hard work and his commitment to principles will continue to contribute to the good of our nation

I also want to thank Ann, the love of my life. She would have been a wonderful first lady. She's - she has been that and more to me and to our family and to the many people she has touched with her compassion and her care.

I want to thank Matt Rhoades and the dedicated campaign team he led.

As stated above in the data above, an anaphoric reference is a backward looking referencing.

(ii) Cataphoric

And to you here tonight, and to the team across the country- the volunteers, the fundraisers, the donours, the surrogates. Besides my wife, Ann, Paul is the best choice I've ever made.

A cataphoric reference is highlighted above, is forward looking. 'you' in the excerpt above looks forward to the audience, the volunteers, the fundraisers and the surrogates.

\section{c. Substitution}

This is a time of great challenges for America, and I pray that the president will be successful in guiding our nation. ...I want to thank Paul Ryan for all he has done for our campaign and for our country. We look to our pastors, and priests and rabbies and counselors of all kinds to testify of the enduring principles upon which our society is built...America - our nation - our country - our society. America is substituted in the speech as shown above to prevent unnecessary tautology/repetition. This implies an American society where everybody's opinion counts.In summary, the study observes that Romney uses simple sentences to express himself to carry his audience along and to drive home his points and ideologies as regards the just concluded elections. The graphetic use of a hyphen (-) was also observed in his speech where he paused to eulogise Ann, 'the love of his life'. He paused so that the audience could feel at that time the significance of Ann being the first lady, just as he is feeling. This is to persuade his audience to appreciate Ann.

\section{Discussion of Findings}

The study observes that the ideologies of political concession speeches are similar in any part of the world. Politicians often concede defeat not to portray themselves as weaklings but for 'peace to reign' and for the love of the people and the country.Politicians in their concession speeches use rhetorical and linguistic elements that are significant in order to reveal the unsaid said in their speeches although they tag them congratulatory speeches but underlyingly they are not. The study also discovered the significant use of pronouns to denote different addressees. The addressees are those who have impacted the lives of the politicians during the preparation for the election in various ways. Also, those that are not parts of the supporters of these politicians are appreciated ironically. These involve the use of pronominal devices.Most 'congratulatory' concession speeches do not congratulate as they rightly make the public to believe, instead, they challenge the lack of credibility of an electoral process in an indirect way. In these concession speeches, we also observed that concession speeches have a similar format. The politicians appreciate the citizens of their countries or state, their party members, pray for the nation or state, point out some electoral inadequacies in an indirect way and thank the nation or state again.

\section{CONCLUSION}


This section has been able to analyse the data (concession speeches of Jonathan, Fayemi and Romney) with a view to identifying the major rhetorical tropes and the cohesive devices like references, substitution, parallelism, conjunction and many other linguistic elements employed in the data to unravel ideological projections. This study is significant because it reveals that behind every concession speech there is an underlying meaning. The ideologies of the politicians whose concession speeches serve as our data are very similar:

1. President Goodluck Jonathan states that 'nobody's ambition is worth the blood of any Nigerian'. This informs that Jonathan's acceptance of the outcome of the election is for peace to reign in Nigeria and to avert the bloodshed of any Nigerian.

2. Fayemi, on his own part conceded defeat for the love of his people. This informs why he tagged the speech 'Will of the People Concession Speech'. He stated that if the outcome of the election was actually the voice of the people, 'they' (all politicians) must heed their voices (the people). It is not surprising to hear that Fayemi has resorted to seek redress in the court on the same election he conceded defeat to. This reveals that his concession speech was actually a conditional one.3. Mitt Romney, on his own part, actually portrays some readiness to work for the people of America but he regretted the fact that they chose another leader. He also expressed that 'Ann, the love of his life' would have been a wonderful first lady. She could not be because the Americans chose President Obama instead of him.Our conclusion from the explanations above informs that behind every politician's mind is the love of his people and the need to allow there to be peace but underlying he is not pleased with the outcome of the election.

\section{REFERENCES}

[1] Blommaert, J. (2005). Discourse: A critical introduction. Cambridge: Cambridge University PressBloor, M. \& Bloor, T. (2006). An Introduction: The practice of critical discourse

[2] analysis. London: Hodder Education.

[3] Cook, G. (1989). Discourse and literature. Oxford: Oxford University Press.Crystal, D. (1991). A dictionary of linguistics and phonetics. Oxford: Basil Blackwell.

[4] Fairclough, N. (1992). Discourse and social change. Cambridge: Polity Press. Fairclough, N. (1993): "Critical discourse analysis and the modification of public

[5] discourse", Discourse \& society. 4.2: 133 - 168. Fairclough, N. (1995a). Media discourse. London: Arnold.Fairclough, N. (1995b): Critical discourse analysis. London: Longman

[6] Fairclough, N. \& Wodak, R. (1997). Critical discourse analysis in Van Dijk (ed):Discourse as social interaction: Discourse studies. London: Sage

[7] Fowler, R., Hodge, B. \& Kress, G. (1979). Language and control. London: Routledge and Kegan PaulFowler, R. (1991). Language in the News: Discourse and ideology in the press. London and

[8] New York: Routledge. Halliday, M. A. K. (1978). Language as social semiotic. London: Edward Arnold Huckin, T. N. (1995). 'Critical discourse Analysis.” In T. Miller (Ed.) Functional

[9] Approaches to Written Texts. Johnstone, B. (2002). Discourse analysis. Massachusetts: Blackwell PublishersJorgenson, M. \& Phillip, L. (2002). Discourse analysis as theory and method. London: Sage

[10] Kamalu, I. \& Agangan, R. (2011). A critical discourse analysis of Goodluck Jonathan's declaration of interest in the PDP presidential primaries. Language, discourse and society. Vol 1: 32-54.

[11] Kamalu, I. \& Otu, O. (2011). Ideology and intertextuality: A critical linguistic analysis of Ben Okri's "An Elegy and Mental Fight" in From boom to doom: Protest and conflict resolution in the literature of the Niger Delta. Nwahunanya, C. (Ed). Owerri: Springfield Publishers Ltd. $571-589$.

[12] Kress, G. (1990). Critical discourse analysis, Robert Kaplan (Ed.). Annual Review of Applied Linguistics 11, pp.8499. Doi:10.1017/s0267190500001975.

[13] Mills, S. (1997). Language arts and disciplines. London: Routledge Newmark, P. (1988). A text of translation. Hertfordshire: Prentice.

[14] Osisanwo, Wale. (2003). Introduction to discourse analysis and pragmatics. Lagos: Femolus-Fetop Publishers.

[15] Paltridge, B. (2006). Discourse analysis: An introduction. London: ContinuumStubbs, M. (1983). Discourse analysis. Oxford: Basil Blackwell.

[16] Taiwo, R. (2007). "Language, Ideology and Power Relations in Nigerian Newspaper Headlines." Nebula 4.1. March, 2007.

[17] Van Dijk, Teun A. (1993). Principles of critical discourse analysis. Sage: London. Discourse and society. Vol 4(2). 249-283.

[18] Wodak, R. (1999). (Ed): Language power and ideology: Studies in political discourse. London: Benjamin Publishing Company.

[19] Wodak, R. \& Meyer, M. (Eds). (2001). Methods of critical discourse analysis. London: Sage.Wodak, R. \& Weiss, G. (Eds). (2003). Critical discourse analysis and the rhetoric of critique. Retrieved from wordpress.com.https:anekawarnapendidikan.files. on 18/6/2015

[20] Woods, N. (2006). Describing Discourse: A practical guide to discourse analysis. London: HodderYule, G. (1996). The study of language (2nd ed.). Cambridge: Cambridge University Press. 